PROPOSAL SKRIPSI

\title{
PENGARUH PENGGUNAAN MEDIA SOSIAL YOUTUBE TERHADAP MOTIVASI BELAJAR SISWA MATA PELAJARAN SEJARAH DI KELAS XI IPS SMA NEGERI 7 BANJARMASIN
}

Disusun Untuk Memenuhi Tugas Mata Kuliah Metode Penelitian KuantitatifKualitatif

DOSEN PENGAMPU :

Prof. Dr. Ersis Warmansyah Abbas, M.Pd Dr. Syaharuddin, S.Pd., M.A.

Heri Susanto, M.Pd.

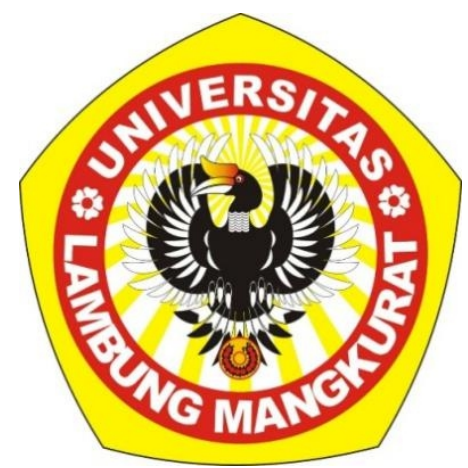

Disusun Oleh:

Mursidul Amin

NIM. 1810111310005

PROGRAM STUDI PENDIDIKAN SEJARAH JURUSAN PENDIDIKAN ILMU PENGETAHUAN SOSIAL

FAKULTAS KEGURUAN DAN ILMU PENDIDIKAN

UNIVERSITAS LAMBUNG MANGKURAT

BANJARMASIN 


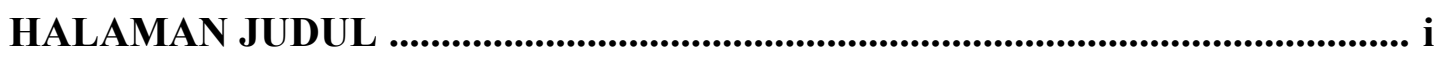

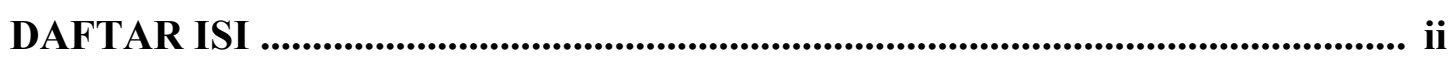

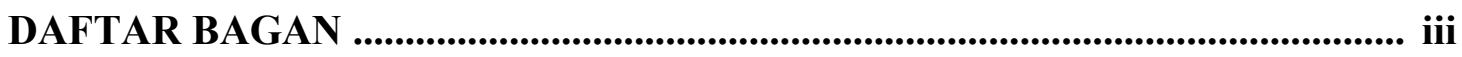

BAB I PENDAHULUAN .......................................................................................... 1

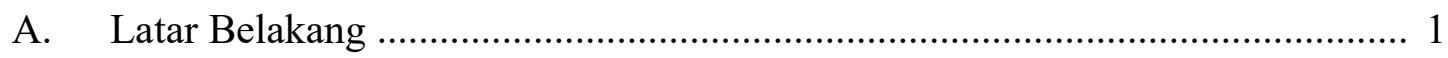

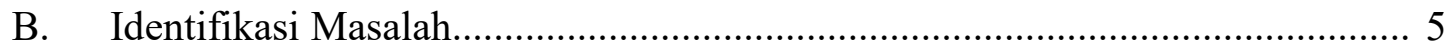

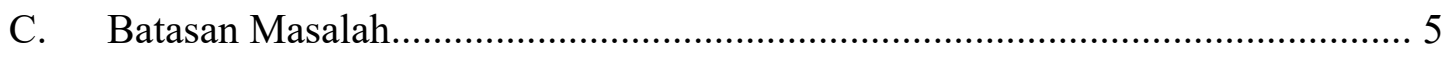

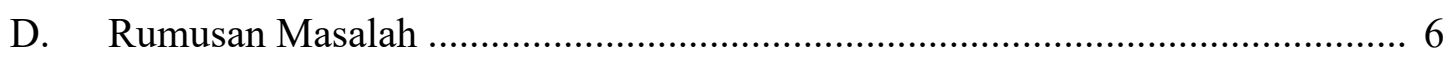

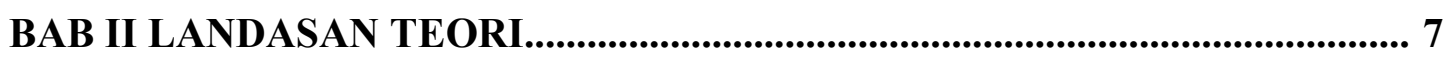

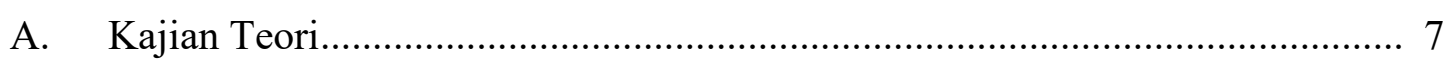

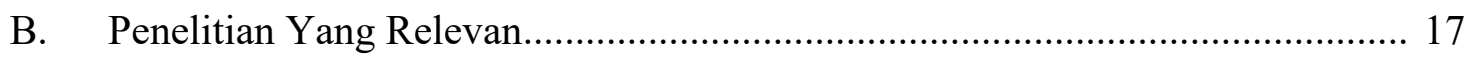

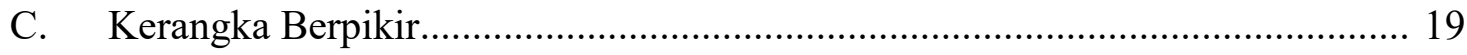

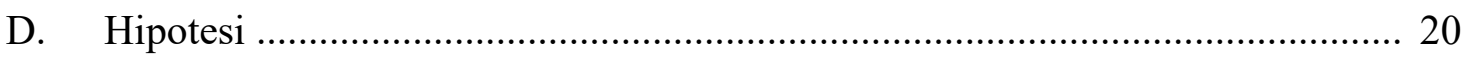

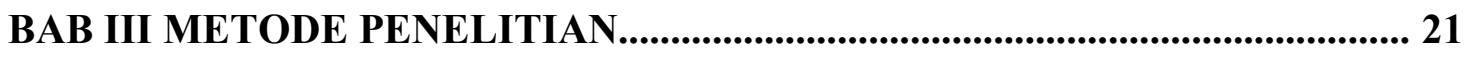

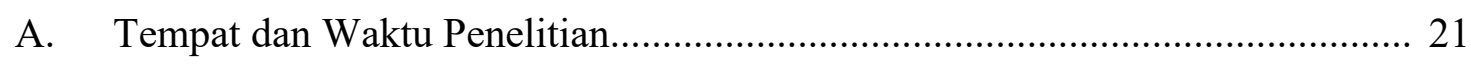

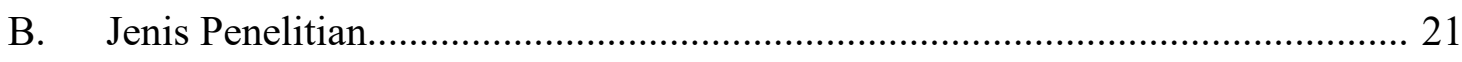

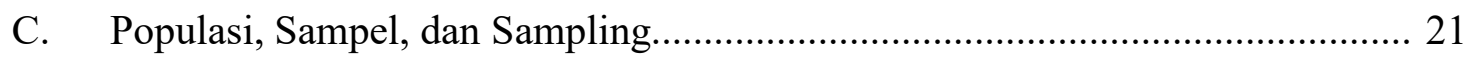

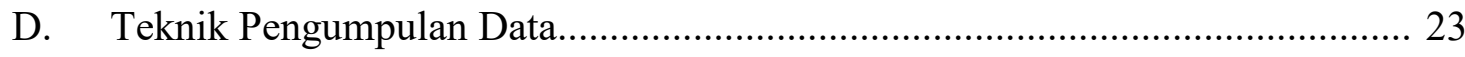

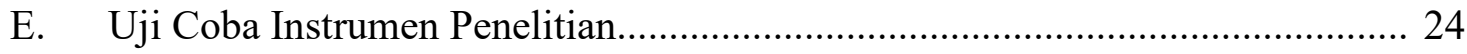

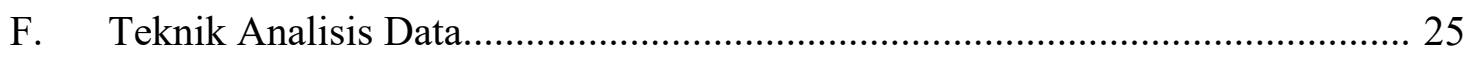

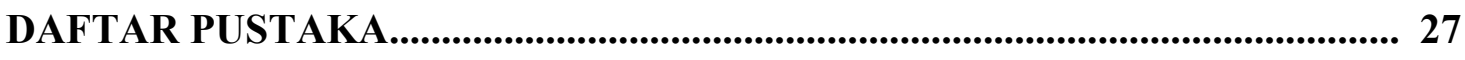




\section{DAFTAR BAGAN}

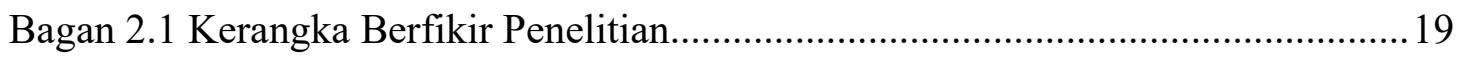

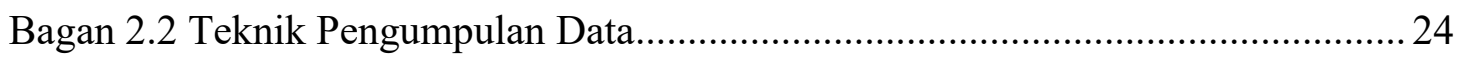




\section{BAB I \\ PENDAHULUAN}

\section{A. Latar Belakang}

Seiring dengan perkembangan globalisasi yang semakin pesat maka tidak menutup kemungkinan bahwa teknologi komunikasi dan media sosial tentunya terkena imbas dari perkembangan yang begitu cepat tersebut. Segala bentuk informasi akan mudah di akses kapan pun dan di mana pun melalui smartphone dan laptop yang terkoneksi dengann jaringan internet (Cahyono, Y. D. 2015:102). sekarang ini banyak sekali penawaran untuk akses jaringan internet murah oleh Provider yang semakin menjamur dan juga adanya program dari pemerintah yang menyalurkan bantuan kuota internet secara gratis ke sekolah-sekolah. Dengan segala kemudahan yang didapat siswa dalam mengakses internet maka secara tidak langsung akan mempengaruhi cara belajar peserta didik dalam mencari sumber-sumber pembelajaran di internet terkait materi yang mereka pelajari (Cahyono, Y. D. 2015:102).

Membahas masalah media sosial tentunya tidak terlepas dari trand dalam berkomunikasi. Menurut Susanto, H., \& Akmal, H. (2019:14) Media berasal dari kata dalam bahasa Latin "medius" yang dalam bentuk jamaknya "medium", diartikan secara harfiah sebagai perantara. Karena itu, dapat dikatakan bahwa segala sesuatu yang dapat menjadi perantara disebut sebagai media. Seperti yang kita ketahui bahwa "Media sosial adalah sebuah media online, dengan para penggunanya bisa dengan mudah berpartisipasi, berbagi, dan menciptakan isi meliputi blog, jejaring sosial, wiki, forum dan dunia virtual" (Cahyono, A. S. 2016: 142). Bentuk media sosial yang sering digunakan oleh masyarakat dunia adalah blog, wiki, dan jejaring sosial. Menurut Andreas Kaplan dan Michael Haenlein (dalam Cahyono, A. S. 2016: 142), mendefinisikan media sosial sebagai "sebuah kelompok aplikasi berbasis internet yang membangun di atas dasar ideologi dan teknologi Web 2.0, dan yang memungkinkan penciptaan dan pertukaran user-generated content". Dengan adanya jejaring sosial ini maka setiap orang dengan bebas bisa membuat web page pribadi sehingga dapat terhubung satu sama lainnya untuk berkomunikasi dan berbagi informasi. Ada beberapa contoh jejaring 
sosial yang berkembang saat ini diantaranya meliputi intragram, twitter, line, facebook, youtube, dan lain-lain.

Azzizah, H. (2020:1) menjelaskan bahwa "[y]outube merupakan situs berbagi media (media sharing), yakni jenis media sosial yang memfasilitasi penggunanya untuk berbagi media, mulai dari video, audio, dan gambar”. Pada awal perkembangannya, youtube bukanlah situs yang dirancang untuk berbagi video tentang pendidikan, namun setelah berjalannya waktu youtube mengalami perkembangan yang pesat dan merekapun meluncurkan layanan khusus untuk pendidikan pada tahun 2009, yang mana layanan tersebut dapat kita akses melalui (www.youtube.com/edu) (Tohari, H., \& Bachri, B. S. 2019:3). keuntungan yang didapat dari penggunaan youtube dalam dunia pembelajaran adalah adanya gambar dan suara dari sebuah peristiwa sehingga peroses pembelajaran dapat dengan mudah dipahami oleh siswa. Menurut Snelson (dalam Tohari, H., \& Bachri, B. S. 2019:3) youtube adalah "salah satu layanan berbagi video di internet yang paling populer saat ini”. pendapat lain mengatakan "youtube merupakan sebuah website yang menfasilitasi penggunanya untuk berbagi video yang mereka miliki, atau sebatas menikmati berbagai video klip yang diunggah oleh berbagai pihak (Putra, G. L. A. K. 2019:264)". Diketahui bahwa banyak sekali jenis video yang dapat di unggah di situs ini, mulai dari video tutorial yang dibuat oleh para orang yang kreatif, video klip musik, video edukasi tentang pendidikan dan masih banyak lagi.

Cepatnya arus globalisasi pada saat ini tentunya berpengaruh pada tuntutan dan motivasi belajar siswa akan lebih tinggi ditambah lagi dengan hadirnya teknologi informasi dalam pembelajaran. Menurut Kim \& W. Frick (dalam Tohari, H., \& Bachri, B. S. 2019:2) "[t]erdapat perubahan motivasi siswa selama Pembelajaran Online, yakni adanya perubahan motivasi yang positif selama self-directed-learning”. Menurut Brown (dalam Tohari, H., \& Bachri, B. S. 2019:3) [m]otivasi didefinisikan sebagai dorongan batin, dorongan hati, emosi atau keinginan yang menggerakkan seseorang ke tindakan tertentu". Dengan kata lain motivasi merupakan keinginan yang timbul dalam diri seseorang baik dari batin, hati, ataupun emosi yang 
menggerakan seseorang dalam melakukan tindakan tertentu, baik itu tindakan positif ataupun negatif. Menurut Astuti (dalam Tohari, H., \& Bachri, B. S. 2019:3) "[m]otivasi belajar adalah sesuatu yang mendorong, menggerakan dan mengarahkan siswa dalam belajar". siswa yang memiliki motivasi tinggi setiap kali mengikuti pembelajaran besar kemungkinan hasil belajarnya akan mengalami peningkatan dibandingkan dengan siswa yang kurang memiliki motivasi dalam belajar. Hal ini diperkuat juga dengan pendapat dari Anderson (dalam Tohari, H., \& Bachri, B. S. 2019:3) "[b]anyak penelitian yang menunjukkan bahwa motivasi belajar siswa terhadap suatu pelajaran merupakan faktor yang mempengaruhi prestasi siswa pada hasil belajarnya".

Menurut Syaharuddin, S., \& Susanto, H. (2019:30) Pendidikan dalam pengertian paling sederhana merupakan proses transfer budaya, yang didalamnya juga meliputi sistem pengetahuan, bahasa, religi, mata pencaharian dan lain sebagainya. Menurut Rasto, R., Mulyasa, E., \& Wasliman, I. (2018:39) "Pemerintah Indonesia, melalui Kementerian Pendidikan Dasar dan Menengah menggelar dan menetapkan sejarah Indonesia sebagai sebuah mata pelajaran yang penting dalam kurikulum 2013, khususnya bagi pendidikan tingkat menengah atas (SMA-sederajat)". Menurut Efendi, I., Prawitasari, M., \& Susanto, H. (2021:21) Kurikulum tidak bisa dipisahkan dari sebuah yang namanya penilaian. Penilaian merupakan salah satu aspek penting dama proses pendidikan. Penilaian adalah langkah yang digunakan untuk penentuan kebijakan proses pembelajaran pada skala kelas ataupun skala Nasional. Pada tingkat SMA mata pelajaran sejarah Indonesia merupakan sebuah mata pelajaran kelolompok wajib A, maka dari itu sekolah menengah tingkat atas yang berada di lingkup Kementrian Pendidikan Dasar dan Menengah dan Kementrian Agama wajib mengangambil mata pelajaran sejarah. Selain itu juga, terdapat juga pembelajaran sejarah yang termasuk dalam kelompok peminatan ilmu-ilmu sosial, bahasa dan menjadi pembelajaran lintas minat (Rasto, R., Mulyasa, E., \& Wasliman, I. 2018:39).

Pendidikan sejarah merupakan media yang sangat cocok untuk digunakan dalam mengenalkan kepada peserta didik tentang sejarah bangsa 
pada masa lalu. Berdasarkan pendapat Hassan (dalam Rasto, R., Mulyasa, E., \& Wasliman, I. 2018:39) mengatakan :

setidaknya ada dua tujuan penting dari pendidikan sejarah, pertama sebagai media yang mampu mengembangkan potensi peserta didik untuk mengenal nilai-nilai bangsa yang terus bertahan, berubah dan menjadi milik bangsa masa kini. Melalui pendidikan sejarah, peserta didik belajar mengenal bangsanya dan dirinya. Tujuan yang kedua adalah sebagai wahana pendidikan untuk mengembangkan disiplin ilmu sejarah.

Menurut apa yang telah di katakan oleh Hassan, pendidikan sejarah memiliki tujuan yang sangat penting dalam membangun potensi peserta didik agar bisa menanamkan nilai-nilai berbangsa dan bernegara. Sedangkan menurut Heri, S. (2014:77) tujuan pembelajaran sejarah adalah siswa memahami dan menghayati nilai-nilai yang terkandung dalam setiap peristiwa sejarah, maka desain pembelajaran yang dibuat harus mampu mengungkapkan nilai-nilai tersebut sehingga mudah dipahami oleh peserta didik. Melalui pendidikan sejarah inilah peserta didik dituntun untuk dapat mengenal siapa dirinya dan juga bangsanya sendiri. Selain sebagai pengenalan terhadap nilainilai berbangsa, pendidikan sejarah juga berperan sebagai wadah pendidikan dalam mengembangan disiplin ilmu sejarah itu sendiri.

Cahyono, Y. D. (2015:103) mengemukakan bahwa, “[p]embelajaran sejarah dikatakan baik jika proses pembelajaran mampu mengembangkan konsep generalisasi dan bahan abstrak dari peristiwa masa lampau dapat menjadi hal yang jelas dan nyata". sedangkan dalam jurnal Susanto, H. (2015:28) pembelajaran sejarah dengan tujuan melatih kemampuan siswa untuk berpikir historis merupakan upaya untuk menjadikan pembelajaran sejarah sebagai media pembentukan keterampilan akademis tingkat tinggi dan pembentukan sikap dan pola perilaku ilmiah. Atas dasar tersebut, proses pembelajaran dapat menumbuhkan motivasi siswa dalam belajar karena siswa akan merasa senang karena dapat melihat dan mendengar langsung sebuah kejadian bersejarah yang dapat mereka tonton langsung di youtube. "Dalam pembelajaran sejarah, media digunakan untuk memvisualisasikan fakta-fakta sejarah dan berfungsi sebagai sumber belajar" (Cahyono, Y. D. 2015:104). Tentunya di zaman sekarang ini seiring dengan kemajuan teknologi informasi, 
hampir semua orang tentunya sudah mengenal youtube. Hal ini tidak lepas dari pengaruh kemudahan dalam mengakses internet. Hal tersebut di sambut positif oleh dunia pendidikan karena dengan kemajuan teknologi seperti sekarang ini peserta didik dapat dengan mudah mencari sumber informasi. Pada youtube sekarang ini banyak sekali video tentang edukasi pendidikan mulai dari informasi seputar pembelajaran bahkan ada video dokumenter yang berguna sekali untuk pembelajaran sejarah.

Bedasarkan uraian latar belakang di atas, peneliti tertarik dan termotivasi untuk melakukan penelitian dan penulisan mengenai pengaruh penggunan media sosial terhadap motivasi belajar siswa mata pelajaran sejarah di kelas XI IPS SMAN 7 Banjarmasin. Oleh karena itu, penelitian ini diberi judul "Pengaruh Penggunan Youtube Terhadap Motivasi Belajar Siswa Mata Pelajaran Sejarah di Kelas XI IPS SMAN 7 Banjarmasin.

\section{B. Identifikasi Masalah}

Berdasarkan identifikasi masalah yang telah diuraikan pada latar belakang di atas, maka dapat diidentifikasikan masalah penelitian ini adalah sebagai berikut :

1) Kemudahan peserta didik dalam mengakses berbagai video di youtube.

2) Dampak positif youtube terhadap motivasi belajar peserta didik.

3) Youtube menjadi salah satu media sosial yang tepat digunakan dalam pembelajaran sejarah.

\section{Batasan Masalah}

Peneliti melakukan pembatasan terhadap masalah-masalah yang akan dibahas, hal ini dilakukan agar pembahsan dalam penelitian ini tidak melenceng dari fokus penelitin.

Adapun batasan masalah dalam penelitian ini adalah sebagai berikut:

1. Penelitian ini dilakukan di SMA Negeri 7 Banjarmasin dengan fokus penelitian peserta didik pada kelas XI IPS

2. Penelitian ini hanya sebatas untuk mengetahui sejauh mana pengaruh penggunaan Youtube terhadap motivasi belajar siswa mata pelajaran sejarah di kelas XI IPS SMAN 7 Banjarmasin 
3. Penelitian ini untuk mengetahui bagiamana motivasi peserta didik terhadap mata pelajaran sejarah yang menggunakan media sosial youtube.

\section{Rumusan Masalah}

Berdasarkan latar belakang dan pembatasan masalah yang telah peneliti kemukakan di atas. Oleh karena itu secara umum peneliti memiliki rumusan masalah sebagai berikut :

1) Bagaimana intensitas penggunaan media sosial youtube di SMA Negri 7 banjarmasin?

2) Adakah pengaruh media sosial youtube terhadap motivasi siswa pada mata pelajaran sejarah di SMA Negri 7 banjarmasin ? 
BAB II

LANDASAN TEORI

\section{A. Kajian Teori}

\section{Kajian Tentang Media Sosial (Youtube)}

\section{a. Pengertian Media Sosial}

Berikut ini adalah defenisi dari media sosial menurut beberapa peneliti :

1) Menurut Andreas Kaplan dan Michael Haenlein

Mendefinisikan media sosial sebagai sebuah kelompok aplikasi berbasis internet yang dibangun diatas dasar ideologi dan teknologi Web 2.0, dan memungkinkan penciptaan dan pertukaran user-generated content.

2) McGraw Hill Dictionary

Media sosial adalah sarana yang digunakan oleh orangorang untuk berinteraksi satu sama lain dengan cara menciptakan, berbagi, serta bertukar informasi dan gagasan dalam sebuah jaringan dan komunitas virtual.

3) Mark Hopkins

Sosial media adalah istilah yang tidak hanya mencakup berbagai platform Media Baru tetapi juga menyiratkan dimasukkannya sistem seperti FriendFeed, Facebook, dan lainlain yang pada umumnya dianggap sebagai jejaring sosial. Idenya adalah bahwa berbagai platform media yang memiliki komponen sosial dan sebagai media komunikasi publik.

4) P.N. Howard dan M.R Parks

Media sosial adalah media yang terdiri atas tiga bagian, yaitu : Insfrastruktur informasi dan alat yang digunakan untuk memproduksi dan mendistribusikan isi media, Isi media dapat berupa pesan-pesan pribadi, berita, gagasan, dan produk-produk budaya yang berbentuk digital, Kemudian yang memproduksi dan mengkonsumsi isi media dalam bentuk digital adalah individu, organisasi, dan industri. 
5) Michael Cross

Media sosial adalah sebuah istilah yang menggambarkan bermacam-macam teknologi yang digunakan untuk mengikat orang-orang ke dalam suatu kolaborasi, saling bertukar informasi, dan berinteraksi melalui isi pesan yang berbasis web. Dikarenakan internet selalu mengalami perkembangan, maka berbagai macam teknologi dan fitur yang tersedia bagi pengguna pun selalu mengalami perubahan. Hal ini menjadikan media sosial lebih hypernym dibandingkan sebuah referensi khusus terhadap berbagai penggunaan atau rancangan.

Dari berbagai depfenisi yang di paparkan oleh beberapa peneliti dapat di ambil kesimpulan bahwa media sosial adalah "medium di internet yang memungkinkan pengguna merepresentasikan dirinya maupun berinteraksi, bekerja sama, berbagi, berkomunikasi dengan pengguna lain, dan membentuk ikatan sosial secara virtua" (Nasrullah 2015:11).

\section{b. Pengertian Media Sosial (Youtube)}

Menurut Huwaidah, A. I. (2019:29) Media sosial youtube adalah salah satu situs yang menyediakan berbagai macam video mulai dari video clip sampai film, serta video-video yang dibuat oleh pengguna youtube itu seendiri. Dengan adanya youtube siswa dapat dengan mudah menikmati media sosial ini dengan cara melihat video atau gambar yang bergerak.

Menurut Baskoro (2009) "[y]outube mempunyai pengertian sebagai situs media digital (video) yang dapat di download, diunggah, serta dibagikan (share) di seluruh penjuru negeri”. Bagi generasi muda youtube merupakan situs media sosial yang fenomenal dan paling sering digunakan. Menurut Sianipar (2013) "youtube ialah sebuah basis data berisi konten video yang populer di media sosial serta penyedia beragam informasi yang sangat membantu". 


\section{c. Kelebihan dan kekurangan media sosial (youtube)}

Youtube banyak memiliki manfaat dan kemudahan sehingga sangat populer sekali bagi penggunanya. Meskipun banyak memiliki manfaat dan kemudahan tidak menutup kemungkinan youtube tidak memiliki kekurangan. Berikut kelebihan dan kekurangan yang dimiliki youtube menurut Mangole, K. D. B., Himpong, M., \& Kalesaran, E. R. (2017:7):

1) Kelebihan

a) Bisa melihat dan mengupload video yang kita suka, sehingga kita sebagai pengguna dapat bebas melihat video yang kita suka dan membuat video kita sendiri.

b) Sebagai ajang promosi diri. Youtube merupakan media yang cocok buat kita untuk menyalurkan bakat yang kita miliki melalui video atau gambar bergerak dan juga cocok buat promosi usaha kita karena youtube memiliki pengguna yang banyak.

c) Bisa mendownload setiap video, sehingga kita dapat menyimpan video yang ingin kita putar nanti seperti siaran langsung di televisi.

d) Bisa belajar streaming, banyak video bermanfaat. Tidak bisa kita pungkiri bahwa media sosial youtube banyak sekali memiliki video-video yang menarik baik di dalam negeri ataupun di luar negeri seperti video tentang edukasi pembelajaran, tutorial, dan masih banyak lagi video yang bermanfaat lainnya.

e) Ukuran yang HD, dengan ukuran gambar video yang sudah bagus sehingga pengguna nyaman dan jelas dalam menonton video yang telah disediakan youtube.

2) Kekurangan

a) Bisa disalahgunakan penggunaannya. 
b) Banyak informarmasi yang menyesatkan, contohnya saja seperti penyebaran berita-berita hoax dan ujaran kebenjian kepada orang ataupun golongan tertentu.

c) Banyak negara yang memblok youtube.

d) Youtube menyediakan untuk penggunanya kebebasan dalam mengupload video, sehingga disini rentan disalah gunakan oleh pihak yang tidak bertanggung jawab. Contohnya seperti penyebaran video porno dan video tidak berguna lainnya.

e) Gambarnya tersendat sendat. Hal ini sering terjadi karena keneksi internet kita lagi lama (lemot), maka dalam menonton video di youtube pun akan terganggu.

f) Banyak video dengan kualitas buruk, sehingga dengan adanya video seperti itu membuat kita merasa tidak nyaman dalam menonton.

\section{d. Kegunaan media sosial youtube dalam pembelajaran}

Pemanfaatan sosial media youtube dalam pembelajaran di sekolah perlu dilakukan karena siswa di era digital seperti sekarang ini tidak lepas dengan sosial media. Berdasarkan pemaparan dari Huwaidah, A. I. (2019:38) :

"[y]outube sebagai media pembelajaran di dalam kurikulum 2013 sangat berguna sebagai bahan pendukung karena youtube mampu memberikan edit value terhadap pendidikan, praktis digunakan dan dapat diikuti oleh semua kalangan termasuk siswa dan guru, memberikan informasi tentang perkembangan ilmu pendidikan, teknologi, kebudayaan, dan ekonomis yaitu gratis untuk semua kalangan ".

Menurut Selwyn (2009) "keunggulan menggunakan sarana sosial media sebagai media pembelajaran terletak pada aspek intelektual dan berbagai informasi yang lebih luas". Pemanfaatan sosial media memberika hasil yang signifikan untuk siswa dalam belajar. Tidak dapat dipungkiri bahwa media sosial youtube menjadi pilihan sebagai sarana dalam proses belajar bagi siswa di era teknologi modern. 
Penggunaan media sosial youtube sebagai media pembelajaran dapat meningkatkan antusias siswa dalam mata pelajaran sejarah karena siswa dapat melihat langsung kejadian-kejadian peristiwa masa lalu melalui video dokumenter yang terdapat banyak di youtube.

Pemanfaatan media sosial youtube sebagai bahan ajar untuk siswa mempunyai manfaat positif dalam proses belajar baik di dalam ataupun di luar lingkungan sekolah. Penggunaan media sosial youtube memberikan kesan positif terhadap mata pelajaran sejarah yang mana kita ketahui bahwa mata pelajaran sejarah terkenal dengan menekankan metode hapalan, akan tetapi dengan adanya media sosial youtube pembelajaran dapat dilakukan secara mengasyikan bahkan menumbuhkan motivasi belajar siswa. Oleh karena itu, youtube dapat menjadi media ajar untuk meningkatkan motivasi dan minat siswa terhadap pembelajaran sejarah.

\section{Kajian tentang Motivasi}

Pada bagian ini akan dipaparkan tentang beberapa hal yang berhubungan dengan motivasi :

\section{a. Pengertian Motivasi}

Menurut David Krec dkk, (dalam Cleopatra, M. 2015:172) "[m]otivasi merupakan suatu tindakan tertentu dimulai dari suatu dorongan". dengan demikian dapat di artikan jika manusia memiliki dorongan, hasrat, ataupun kebutuhan maka dapat di katakan manusia itu memiliki motivasi dalam hidup. Senada dengan apa yang dikemukan oleh david kreck dkk, Meggison Byrd Meggison (dalam Cleopatra, M. 2015:172) berpendapat "motivasi adalah suatu pernyataan yang muncul dalam diri seseorang, termasuk dorongan, hasrat dan motif'. Jadi dapat di artikan bahwa motivasi merupakan bagian yang ada didalam diri seseorang untuk melakukan tindakan secara jeles, untuk memenuhi beberapa tujuan tertentu. Motivasi memberikan pemahaman mengapa orang melakukan suatu tindakan. Hal ini berpengaruh terhadap apa yang dilakukan, misalnya seorang 
pemimpin memberikan motivasi dalam meningkatkan kinerja sebuah organisasi (Cleopatra, M. 2015:172).

Menurut Amo F. Wittig (dalam Cleopatra, M. 2015:172) berpendapat bahwa motivasi adalah movere yang berasal dari bahasa latin yang berarti daya penggerak atau dorongan dalam diri seseorang untuk berperilaku dan bertindak yang diarahkan dalam upaya mencapai tujuan tertentu. Dorongan diri seseorang dalam berperilaku ini secara terus menerus dipertahankan hingga hingga tujuan yang diinginkan dapat tercapai. Hal ini juga di katakan oleh serang peneliti yang bernama Crawford (dalam Cleopatra, M. 2015:172) yang berpendapat bahwa motivasi merupakan tenaga penggerak, inilah yang menjadi unsur determinan dalam mempengaruhi kesiapan seseorang untuk memulai melakukan serangkaian kegiatan. Kemunculan motivasi berawal dari kebutuhan dan dorongan. Dalam mengambil keputusan seseorang harus memiliki kebutuhan atau dorongan yang kuat untuk bertindak. Oleh karena itu, David Krech dkk (dalam Cleopatra, M. 2015:173) berpendapat secara lugas mengungkapkan kebutuhan primer merupakan kekuatan pendorong bagi manusia untuk bertindak.

Menurut Umar. H. (2005) ada dua pendekatan yang dapat dilakukan untuk memhami motivasi, (1) motivasi dipandang sebagi suatu proses. Guru dapat menjelaskan atau meramal tingkah laku siswa dengan memhami suatu proses yang dilakukan siswa. (2) menentukan karakteristik proses ini berdasarkan petunjuk-petunjuk tingkah laku seseorang. Menurut John P. Campbell (dalam Cleopatra, M. 2015:173) Ada tiga unsur motivasi yang saling berkaitan. Unsurunsur ini ialah sebagai berikut : (1) arah perilaku, (2) kekuatan respon setelah seseorang memilih, mengikuti tindakan tertentu, (3) kelangsungan perilaku/beberapa lama orang tersebut terus berperilaku menurut cara tertentu.

Motivasi pada hakikatnya adalalah faktor rangsangan yang terjadi secara internal maupun eksternal yang datang dari luar, dengan 
adanya rangsangan tersebut menyebabkan manusia dapat bersikp dan berperilaku. Hal ini berarti motivasi adalah kekuatan dalam jiwa yang harus diterjemahkan oleh seseorang kedalam bentuk perilaku yang sesuai dengan tuntutan yang timbul dari dalam dirinya maupun oleh dorongan dan lingkungannya (Cleopatra, M. 2015:173).

Dari uraian diatas dapat dijelaskan bahwa motivasi adalah dorongan, hasrat, kebutuhan seseorang dalam melakukan aktivitas tertentu dalam hal ini adalah untuk motivasi belajar. Motivasi pada hakikatnya merupakan faktor rangsangan yang terjadi baik secara internal maupun eksternal, yang selanjutnya akan menyebabkan manusia manusi mengalami rangsangan atau dorongan dan kemudian bersikap dan berperilaku. Hal ini berarti motivasi adalah merupakan seperangkat daya ataupun kekuatan dalam jiwa yang harus diterjemahkan oleh seseorang kedalam bentuk perilaku yang sesuai dengan tuntutan yang timbul dari dalam (internal) dirinya maupun oleh dorongan dan lingkungannya (eksternal) (Cleopatra, M. 2015:174).

Guru dituntut untuk bisa membangkitkan motivasi dalam diri siswa agar mereka semakin aktif dalam mengikuti pembelajaran sehingga dapat mencapai keberhailan dalam belajar. Siswa yang memiliki motivasi belajar yang tinggi sangat berpeluang besar dalam memperoleh hasil belajar yang baik, sebab siswa akan berusaha semaksimal mungkin dengan daya upaya mempelajari mata pelajaran. Oleh sebab itu, motivasi dalam belajar sangat penting untuk mencapai keberhasilan siswa. Menurut Sidjabat, B. S. (dalam Saptono, Y. J. 2016:201) "kalau ada peserta didik yang kurang bergairah dalam mengikuti pelajaran, guru harus sadar bahwa barangkali metode atau pendekatan yang dipilihnya kurang relevan dan ia harus berusaha mencari metode alternatif".

\section{b. Ciri-ciri Motivasi}

Motivasi merupakan seluruh aktivitas mental yang dirasakan atau dialami yang memberikan kondisi hingga terjadinya perilaku. 
Menurut Wasty Soemanto, P. P. (dalam Saptono, Y. J. 2016:201) Motivasi dapat diidentifikasidalam beberapa ciri berdasarkan hubungannya dengan perilaku, yakni:

(1) Motivasi tidak hanya merangsang suatu perilaku tertentu saja, tetapi merangsang berbagai kecenderungan berperilaku yang memungkinkan tanggapan yang berbeda. (2) Kekuatan dan efisiensi perilaku mempunyai hubungan yang bervariasi dengan kekuatan determinan. (3) Motivasi mengarahkan perilaku pada tujuan tertentu. (4) Penguatan positif (positivereinforcement) menyebabkan suatu perilaku tertentu cenderung untuk diulangi kembali. (5) Kekuatan perilaku akan melemah bila akibat dari perbuatan itu bersifat tidak enak.

Irwanto (dalam Saptono, Y. J. 2016:201) berpendapat bahwa berdasarkan sifatnya, motivasi dapat dibedakan dalam beberapa ciri, yakni: 1) motivasi yang bersifat mental (seperti: cita-cita, rasa tanggung jawab), 3) motivasi yang bersifat objek atau kondisi dalam lingkungan (uang, pangkat, rencana). Wasty Soemanto, P. P. (dalam Saptono, Y. J. 2016:202) menjelaskan berdasarkan terjadinya perilaku, motivasi juga dapat dibedakan dalam 3 ciri, yaitu : Motivasi yang berasal dari lingkungan (kegaduhan, bahaya dari lingkungan, desakan guru, dan lain-lain), 2) Motivasi yang berasal dari dalam diri individu (harapan/cita-cita, emosi, instink, keinginan, dan lain-lain), 3) Motivasi yang berasal dari tujuan/insentif/nilai dari suatu objek. Hal ini ada yang berasal dari dalam diri individu (kepuasan kerja, tanggung jawab, dan lain-lain) dan hal yang berasal dari luar individu (status, uang, dan lain-lain).

Sudirman (dalam Saptono, Y. J. 2016:202) juga mencoba menjelaskan ciri-ciri motivasi berdasarkan teori psikoanalitik. Ciriciri motivasi tersebut antara lain :

1) Tekun menghadapi tugas (dapat bekerja terus menerus dalam waktu yang lama, tidak pernahberhenti sebelum selesai). 2) Ulet menghadapi kesulitan (tidak lekas putus asa). 3) Menunjukkan minat terhadap bermacam-macam masalah "untuk orang dewasa" (misalnya masalah pembangunan agama, politik, ekonomi, keadilan, pemberantasan korupsi, penentangan terhadap setiap tindak kriminal, amoral dan sebagainya). 4) Lebih senang bekerja mandiri. 5) Cepat bosan pada tugas-tugas yang rutin (hal-hal 
yang bersifat mekanis, berulang-ulang begitu saja sehingga kurang kreatif). 6) Dapat mempertahankan pendapatnya (kalau sudah yakin akan sesuatu). 7) Tidak mudah melepaskan hal yang diyakini itu. 8) Senang mencari dan memecahkan masalah soalsoal.

Besarnya tingkatan motivasi seseorang dengan orang lain tidaklah sama. Besarnya tingkatan motivasi itu hanya dapat diamati pada efek perbuatan yang dihasilkannya, yaitu dengan melihat daribeberapa aspeknya, antara lain: 1) seberapa besar tenaga yang dipergunakan, 2) seberapa besar gigihnya usaha meskipun menghadapi bermacam-macam rintangan, 3) seberapa banyak macam cara pendekatan yang berguna untuk dapat mencapai tujuan yang diinginkan (Saptono, Y. J. 2016:203).

\section{c. Jenis-jenis Motivasi Belajar}

Ada dua macam motivasi berdasarkan sumber dorongan, yaitu motivasi intrinsik dan ekstrinsik. Motivasi intrinsik mempunyai sumber dorongan dari dalam diri individu yang bersangkutan, sedangkatan motivasi ekstrinsik mempunyai sumberdorongan dari luar. Oleh karena itu, Engkoswara dan Aan Komariah (dalam Saptono, Y. J. 2016:203) menegaskan bahwa baik motivasi intrinsik maupun motivasi ekstrinsik timbul karena adanya rangsangan.

1) Motivasi Instrinsik

Menurut Saptono, Y. J. (2016:203) "Motivasi intrinsik adalah perubahan yang terjadi didalam diri seseorang, keadaan merasa tidak puas atau ketegangan psikologis". Dalam aktivitas pembelajaran, motivasi instrinsik sangat dibutuhkan, terutama untuk belajar sendiri. Siswa yang tidak memiliki motivasi instrinsik akan kesulitan dalam melakukan aktivitas belajar yang terus menurus. Berbeda halnya dengan siswa yang memiliki motivasi instrinsik ia akan selalu ingin belajar, keinginan itu timbul oleh pemikiran yang positif, bahwa semua mata pelajaran yang di pelajari sekarang ini akan sangat berguna untuk masa depan. Dengan demikian motivasi instrinsik akan tumbuh 
berdasarkan kesadaran dengan tujuan esensial, bukan sekedar atribut dan seremonial semata.

2) Motivasi Ekstrinsik

Menurut Saptono, Y. J. (2016:203) "motivasi ekstrinsik adalah apa yang diinginkan seseorang, tujuan yang menjadi arah kelakuan atau tujuan yang hendak dicapai oleh seseorang”. motivasi belajar dikatakan ekstrinsik bila siswa mendapat tujuan belajar di luar faktor-faktor situasi belajar. Berbagai penelitian menunjukan bahwa motivasi instrinsik akan bertahan lebih lama dan lebih kuat dalam diri siswa dibandingkan dengan motivasi ekstrinsik dalam mendorong minat siswa untuk belajar. Namun demikian, motivasi ekstrinsik juga sangat berguna karena minat siswa tidak selalu tumbuh dari motivasi intrinsik.

\section{d. Strategi Meningkatkan Motivasi Belajar Siswa}

Motivasi belajar memiliki peran yang sangat penting dalam keberhasilan siswa di sekolah. Meskipun kegiatan belajar tidak mudah, namun siswa akan akan selalu berusaha melakukan dan menyelesaikan tugasnya dengan sebaik mungkin. Persoalan yang timbul adalah kenapa masih ada siswa yang kelihatan kurang memiliki motivasi dalam belajar pada mata pelajaran tertentu sedangkan pada mata pelajaran lain dia penuh semangat dalam mempelajarinya. Untuk mengatasi hal tersebut guru perlu strategi dalam meningkatkan motivasi belajar siswa pada mata pelajaran yang kurang diminatinya.

Winkel (dalam Saptono, Y. J. 2016:208) menjelaskan ada beberapa strategi yang dapat dilakukan guru dalam meningkatkan motivasi belajar siswa di sekolah, yaitu :

1) Memberikan kontiguitas, peneguhan/penguatan serta hukuman dengan berpijak pada pandangan behavioristik. ;2) Memberikan kebebasan pribadi, hak untuk memilih sendiri, pengaturan diri dan penentuan diri, kecenderungan untuk mengembangkan diri serta memperkaya diri dengan berpijak pada pandangan humanistik; 3) Memberikan keyakinan, tujuan, penafsiran, harapan, minat dan kemampuan dalam diri peserta didik dengan berpijak pada pandangan kognitif; 4) Memberikan pengharapan 
dan penghargaan kepada peserta didik dengan berpijak pada pandangan belajar sosial (sociallearning).

Starategi di atas dapat diterapkan oleh guru dalam meningkatkan motivasi belajar siswa karena sudah sesuai dengan proses belajar mengajar karena lebih menekankan aspek pedagogis-psikologis. Oleh sebab itu, siswa perlu bimbingan agar memiliki motivasi belajar yang tinggi dan konsisten. Tugas guru dalam membangkitkan motivasi belajar siswa dapat dilakukan dengan beberapa usaha, seperti : memberikan tugas untuk pendalaman materi, menciptakan suasana kelas yang kondusif, menumbuhkan harapan dalam diri peserta didik danmengajar dengan cara yang membangkitkan semangat belajar.

Strategi utama dalam meningkatkan dan membangkitkan motivasi belajar siswa pada dasarnya terletak pada guru sendiri. Mc. Keachie (dalam Saptono, Y. J. 2016:210) menyatakan bahwa kemampuan guru menjadikan dirinya model yang mampu membangkitkan rasa ingin tahu dan kesanggupan dalam diri peserta didik merupakan aset utama dalam memotivasi.

Dalam hal ini, guru harus menekankan pentingnya berdoa dan belajar lebih keras dalam mencapai keberhasilan belajar. Dengan melakukan hal tersebut siswa telah memulai pembelajaran dengan hal yang positif dalam pikirannya sehingga memungkinkan mereka melakukan tindakan-tindakan yang positif. Keadaran akan janji Tuhan yang merancangkan masa depan yang penuh harapan dan manfaat pengetahuan yang didapat akan sangan efektif dalam meningkatkan motivasi belajar siswa. Oleh karena itu, guru perlu melibatkan siswa di sekolah dan keluarga dirumah dalam proses pembelajaran secara berkelanjutan.

\section{B. Penelitian yang Relevan}

Tohari, H., \& Bachri, B. S. Dalam penelitian yang berjudul "Tohari, H., \& Bachri, B. S. Pengaruh Penggunaan Youtube Terhadap Motivasi Belajar Dan Hasil Belajar Mahasiswa” Relevansi dengan penelitian ini yaitu samasama melakukan penelitian mengenai pengaruh penggunaan media sosial 
youtube terhadap motivasi belajar. Meskipun tidak sama persis, karena dalam penelitian yang dilakukan oleh Tohari, H., \& Bachri, B. S. tujuan penelitiannya kemahasiswa dan juga ada membahas tentang hasil belajar. Sedangkan dalam penelitian ini, fokusnya terhadap pengaruh penggunaan youtube terhadap motivasi siswa mata pelajaran sejarah di kelas xi ips sma negeri 7 banjarmasin.

Iwantara, I. W.dkk (2014) Dalam Penelitian yang berjudul "Pengaruh penggunaan media video youtube dalam pembelajaran IPA terhadap motivasi belajar dan pemahaman konsep siswa" relevansi dengan penelitian ini yaitu sama-sama membahas mengenai pengaruh penggunaan media video youtube tehadap motivasi belajar siswa. Meskipun tidak sama persis karena dalam penelitian yang dilakukan Iwantara, I. W. dkk ada membahas tentang pemahaman konsep siswa. Sedangkan dalam penelitian ini hanya fokus ke motivasi belajar siswa.

Huwaidah, A. I. (2019) Dalam penelitian ini yang berjudul "pengaruh penggunaan media sosial youtube terhadap kreativitas siswa pada mata pelajaran seni budaya dan prakarya di sdn 1 nologaten ponorogo tahun ajaran 2018/2019” Meskipun penelitian ini tidak sama persis karena dalam penelitian yang dilakukan oleh Huwaidah, disini penelitiannya membahas tentang pengaruh media sosial youtube terhadap kreativitas siswa. Sedangkan dalam penelitian ini membahas tentang pengaruh penggunaan youtube terhadap motivasi belajar. Meskipun sama-sama melakukan penelitian mengenai pengaruh penggunaan media sosial youtube.

Pambudi, R., Afghohani, A., \& Farahsanti, I. (2019) Dalam penelitian yang berjudul "Pengaruh Media Video Youtube Terhadap Prestasi Belajar Matematika Pada Siswa Kelas X SMK Negeri 2 Sukoharjo Tahun Ajaran "Relevansi dengan penelitian ini yaitu dalam yang dilakukan oleh Pambudi, R., Afghohani, A., \& Farahsanti, I. membahas tentang pengaruh media video youtube terhadap prestasu belajar Matematika. Sedangkan dalam penelitian ini membahas tentang pengaruh penggunaan youtube terhadap motivasi belajar siswa mata pelajaran sejarah. 


\section{Kerangka Berpikir}

Pada dasarnya proses belajar mengajar merupakan usaha sadar untuk membawa peserta didik ke arah perubahan tingkah laku baik itu secara intelektual maupun secara moral. pembelajaran sejarah di anggap tidak lebih dari rangkaian angka tahun dan urutan peristiwa yang di harus ingat kemudian diungkap kembali saat menjawab soal-soal ujian. Pelajaran sejarah sangat penting diberikan kepada peserta didik karena dengan mempelajari sejarah peserta didik dapat mengetahui peristiwa-peristiwa yang terjadi pada masa lampau dan dapat mengambil hikmah dari peristiwa tersebut. namun selama ini pembelajaran sejarah kurang diminati oleh peserta didik karena dianggap membosankan dan sekedar hafalan saja. Selain itu guru hanya memberikan ceramah dan terfokus pada sumber belajar buku saja yang membuat peserta didik menjadi bosan. Oleh karena itu penggunaan media sosial youtube dalam pembelajaran sejarah sangatlah penting karena akan menimbulkan pariasi dalam pembelajaran. Karena dengan memanfaatkan media sosial youtube akan dapat menumbuhkan motivasi belajar siswa dengan baik.

Kenyataan ini tidak dapat di pungkiri, karena masih banyak terjadi sampai sekarang. Salah satu rahasia umum dan hampir terjadi di kebanyakan sekolah yang pernah peneliti jumpai, guru hanya menggunakan buku paket maupun bukul Lembar Kerja Siswa (LKS) sebagai sumber belajar dalam pembelajaran sejarah. dimana guru hanya fokus membacakan isi LKS tanpa ada pariasi pembelajaran sehingga dapat membuat siswa merasa cepat bosen, seharusnya guru mampu untuk memanfaatkan perkembangan media sosial dengan menggunakan youtube dalam pembelajarannya, agar siswa bisa melihat peristiwa masa lalu secara langsung lewat video yang ada di youtube agar siswa termotivasi dalam belajar sejarah.

Adapun secara skematis dapat digambarkan kerangka berpikir penelitian ini sebagai berikut :

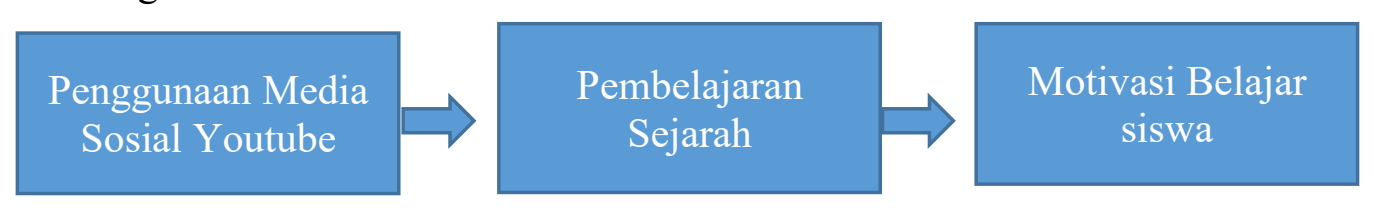

Bagan 2.1 Kerangka Berpikir Penelitian 
Berdasarkan bagan 2.1 diatas, dapat diketahui bahwa penelitian ini dilakukan untuk mengetahui pengaruh penggunaan media sosial youtube terhadap motivasi belajar siswa mata pelajaran sejarah di kelas XI IPS SMA Negeri 7 Banjarmasin.

\section{Hipotesis}

Hipotesis merupakan dugaan sementara yang masih perlu dibuktikan melalui suatu penelitian. Hipotesis terbentuk sebagai hubungan antara dua variabel atau lebih. Untuk mengetahui gambaran jawaban yang bersifat sementara dari peneliti ini, maka diperlukan hipotesis. Adapun hipotesis dalam penelitian ini adalah :

Ho : Tidak ada pengaruh signifikan antara penggunaan media sosial youtube terhadap motivasi siswa pada mata pelajaran sejarah di kelas XI IPS SMA Negeri 7 Banjarmasin

Ha : Terdapat pengaruh signifikan antara penggunaan media sosial youtube terhadap motivasi siswa pada mata mata pelajaran sejarah di kelas XI IPS SMA Negeri 7 Banjarmasin 


\section{BAB III}

\section{METODE PENELITIAN}

\section{A. Tempat dan Waktu Penelitian}

1. Tempat Penelitian

Penelitian ini akan dilaksanakan di SMA Negeri 7 Banjarmasin yang beralamat di J1. Dharma Praja V No. 47, Pemurus Luar, Kecamatan Banjarmasin Timur, Kota Banjarmasin, Kalimantan Selatan. Pemilihan sekolah ini didasarkan pada beberapa alasan berikut, yaitu:

a. SMA Negeri 7 Banjarmasin merupakan sekolah yang telah mendapatkan status akreditasi A (sangat baik).

b. SMA Negeri 7 Banjarmasin telah menerapkan kurikulum 2013 sehingga proses pembelajaran untuk setiap mata pelajaran diwajibkan menggunakan pendekatan saintifik yang mengharuskan peserta didik berperan aktif secara mandiri dalam kegiatan pembelajaran.

c. SMA Negeri 7 Banjarmasin sudah memiliki fasilitas pembelajaran yang baik, sehingga dapat memudahkan dalam proses pembelajaran menggunakan media sosial.

Berdasarkan ketiga alasan tersebut, maka penelitian ini akan dilakukan di SMA Negeri 7 Banjarmasin.

2. Waktu Penelitian

Waktu penelitian ini akan dilaksanakan pada semeter ganjil tahun ajaran 2021/2022 pada bulan September 2021.

\section{B. Jenis Penelitian}

Jenis penelitian yang digunakan dalam penelitian ini yaitu Penelitian Kualitatif dengan menggunakan metode Eksperimen.

\section{Populasi, Sampel, dan Sampling}

1. Populasi

Menurut Siswono (2011) Dalam suatu penelitian, yang dimaksud populasi adalah wilayah generalisasi yang terdiri atas objek / subjek yang mempunyai kualitas dan karakteristik tertentu yang ditetapkan oleh peneliti untuk dipelajari dan kemudian ditarik kesimpulannya. Sedangkan Menurut Margono (dalam Saputra, M. R., \& Riyadi, S. 
2019:1) "Populasi merupakanseluruh data yang menjadi pusat perhatian seorang peneliti dalam ruang lingkup \& waktu yang telah ditentukan”. Populasi berkaitan dengan data-data. Jika setiap manusia memberikan suatu data, maka ukuran atau banyaknya populasi akan sama dengan banyaknya manusia. Populasi yang dilakukan dalam penelitian ini adalah kelas XI IPS SMA Negeri 7 Banjarmasin, terdiri dari dua kelas yang berjumlah keseluruhan 70 siswa dengan rincian kelas XI IPS 1 sebanyak 36 siswa sedangkan kelas XI IPS 2 sebanyak 34 siswa.

2. Sampel

Pengertian sampel menurut Arikunto (2002:109) menyatakan bahwa sampel adalah sebagian atau wakil populasi yang diteliti. Dinamakan penelitian sampel apabila kita bermaksud untuk menggeneralisasi hasil penelitian sampel.

Adapun sampel yang digunakan dalam penelitian ini adalah du kelas yaitu kelas XI IPS 1 dan Kelas XI IPS 2 SMA Negeri 7 Banjarmasin, dimana kelas XI IPS 1 jumlahnya 36 sebagai kelas eksperimen dan kelas XI IPS 2 jumlahnya 34 sebagai kelas kontrol. Dengan demikian sampel keseluruhan berjumlah 70 peserta didik.

3. Sampling

Menurut Supranto (2007) sampling adalah cara pengumpulan data atau penelitian kalau hanya elemen sampel (sebagian dari elemen populasi) yang diteliti. Dalam pengambilan sampel ini harus dilakukan dengan teliti agar diperoleh sampel yang benar-benar dapat berfungsi atau dapat menggambarkan keadaan populasi yang sebenarnya.

Dalam penelitian ini teknik sampling yang digunakan adalah purposive sampling. Hal ini dilakukan karena kelas yang ada di SMA Negeri 7 Banjarmasin hanya ada dua kelas untuk IPS XI. Berdasarkan informasi guru sejarah bahwa kedua kelas tersebut memiliki kemampuan yang hampir sama dan kelas tersebut telah mendapat materi pelajaran sejarah yang sama. 


\section{Teknik Pengumpulan Data}

Pengumpulan data dalam penelitian yang dilakukan ini adalah untuk mengetahui bagaimana pengaruh penggunaan media sosial youtube terhadap motivasi siswa mata pelajaran sejarah di kelas XI IPS SMA Negeri 7 Banjarmasin. Pada penelitian ini teknik pengumpulan data yang di lakukan dengan :

1. Observasi

Observasi atau pengamatan adalah kegiatan pemuatan perhatian terhadap suatu objek yang diteliti dengan menggunakan seluruh indra (Arikunto, 2010). Observasi yang akan dilakukan peneliti adalah penelitian yang akan dilakukan baik secara langsung maupun tidak langsung terhadap sesuatu yang berhubungan dengan apa yang diteliti. Observasi dilakukan mengenai pengaruh penggunaan media sosial youtube terhadap motivasi siswa mata pelajaran sejarah di kelas XI IPS SMA Negeri 7 Banjarmasin.

2. Tes

Menurut Arikunto Iskandar wassid (dalam Ambarawati, F 2017) Tes adalah suatu alat atau prosedur yang sistematis dan objektif untuk memperoleh data-data atau keterangan-keterangan yang diinginkan tentang seseorang, dengan cara yang boleh dikatakan tepat dan tepat. Tes adalah serangkaian pertanyaan-pertanyaan kepada siswa untuk mendapatkan jawaban baik secara lisan maupun tulisan, ataupun juga dalam bentuk tindakan. Pada dasarnya tes digunakan untuk menilai hasil belajar siswa, terutama dalam hasil belajar kognitif yang berkenaan pada penguasaan bahan pengajaran sesuai dengan tujuan pendidikan. Menurut nana sudjana sesungguhnya, tes juga dapat digunakan untuk mengukur atau menilai hasil belajar bidang efektif dan psikomotorik.

Dalam penelitian ini, peneliti menggunakan hasil tes belajar yang digunakan untuk mengukur sejauh mana pengaruh penggunaan media sosial youtube terhadap motivasi siswa mata pelajaran sejarah di kelas XI IPS SMA Negeri 7 Banjarmasin. Penelitian dalam tes ini dilakukan dengan cara memberikan soal uraian (essay) yang sama kepada kedua 
kelas XI IPS 1 sebagai kelas Eksperimen dan kelas XI IPS 2 sebagai kelas kontrol.

Tujuan peneliti memilih tes dalam bentuk uraian adalah karena tes uraian dapat mengukur proses mental, dapat mengembangkan kemampuan berbahasa, dapat melatih kemampuan menalar, dan juga dapat mengembangkan kemampuan keterampilan memecahkan suatu masalah. Hal di atas tersebutlah yang ingin diharapkan peneliti untuk melakukan tes dalam pengumpulan data.

Secara skematis dapat digambarkan teknik pengumpulan data dalam penelitian yang di lakukan kepada siswa kelas XI IPS SMA Negeri 7 Banjarmasin ini sebagai berikut :

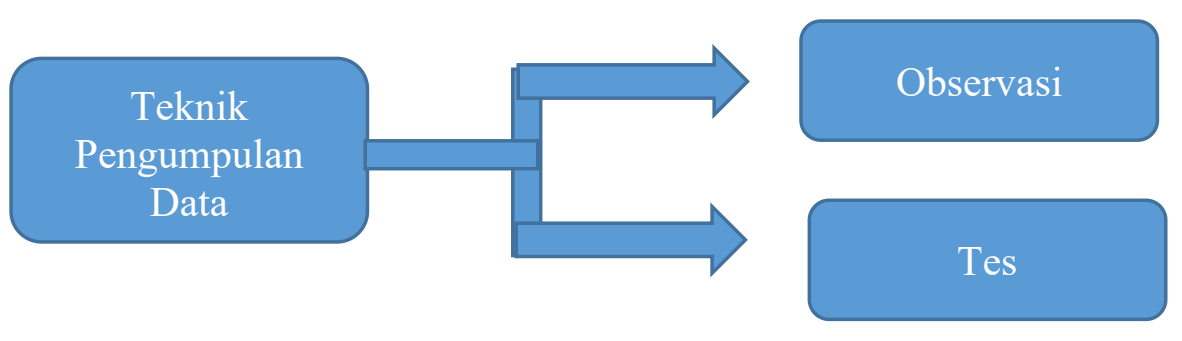

\section{Bagan 2.2 Teknik Pengumpulan Data}

\section{E. Uji Coba Instrumen Penelitian}

\section{Uji Validitas}

Validitas berasal dari bahasa Latin validus yang berarti kuat, "strong", "robust". Pertama-tama perlu dibedakan dua buah konsep validitas: (1) Validitas penelitian; dan (2) Validitas pengukuran. Menurut Ihsan, H. (2015) "Validitas adalah sejauh mana tes itu mengukur apa yang dimaksudkan untuk diukur”. Sedangkan menurut Murti, B. (2011) menjelaskan bahwa :

Validitas pengukuran menentukan validitas penelitian. Jika pengukuran salah, maka kesimpulan penelitian juga salah.Jelas validitas pengukuran sangat vitalbagi validitas sebuah penelitian.Validitas pengukuranmencakup 4 aspek: (1) Validitas isi; (2) Validitasmuka; (3) Validitas konstruk; (4) Validitas kriteria. 
Validitas berasal dari kata validity yang memiliki arti sejauh mana ketetapan dan kecermatan suatu alat ukur dalam melakukan fungsi ukurannya.

2. Uji Reliabilitas

Reliabilitas berasal dari kata reliability. Menurut Suharsimi Arikunto (2010 : 221) "Reliabilitas menunjuk pada satu pengertian bahwa sesuatu instrumen cukup dapat dipercaya untuk digunakan sebagai alat pengumpul data karena instrumen tersebut sudah baik". Suatu tes dapat dikatakan mempunyai taraf yang tinggi jika tes tersebut dapat memberikan hasil yang teteap. Hasil pengukuran haruslah reliabel atau harus memiliki tingkat konsistensi. Reliabilitas dapat diartikan sebagai konsistensi dari serangkaian pengukuran.

\section{F. Teknik Analisis Data}

Teknik analisis data diartikan sebagai upaya mengolah data menjadi informasi, sehingga karakteristik atau sifat-sifat data tersebut dapat dengan mudah dipahami dan bermanfaat untuk menjawab masalah-masalah yang berkaitan dengan kegiatan penelitian. Teknik analisis data yang digunakan dalam penelitian ini adalah eksperimen.

Dalam melakukan uji syarat penelitian maka diperlukan uji normalitas dan uji homogenitas pada data yang akan dianalisis.

1. Uji Normalitas

Uji Normalitas adalah sebuah uji yang dilakukan dengan tujuan untuk menilai sebaran data pada sebuah kelompok data atau variabel, apakah sebaran data tersebut berdistribusi normal ataukah tidak.

Menurut Riduwan (2006:180) uji normalitas menggunkan rumus chisquareatau chi kuadrat. Adapun langkah-langkah pengujian normalitas sebagai berikut:
a. Mencari skor terbesr dan terkecil
b. Mencari nilai rentang
c. Mencari banyaknya kelas
d. Mencari nilai panjang kelas 
e. Membuat tabulasi dengan tabel penolong

f. Mencari rata-rata

g. Mencari simpangan baku

h. Membuat daftar frekuensi yang diharapkan

i. Mencari luas $0-Z$

j. Mencari luas tiap kelas interval

k. Mencari frekuensi harapan

1. Mencari chi kuadrat hitung dengan rumus

$$
x^{2}=\sum_{i=1}^{k} \frac{\left(f_{0}-f_{s}\right)^{2}}{f_{g}}
$$

m. Membandingkan chi kuadrat hitung dengan chi kuadrat tabel

Setelah dibandingkan langkah selanjutnya mengambil keputusan dengan ketentuan sebagai berikut:
a. Taraf signifikan $\alpha=5 \%$
b. ${ }^{x_{\text {hitung }}^{2}} \leq x_{\text {tabel }}^{2}$ artinya data terdistribusi normal

2. Uji Homogenitas

Uji homogenitas ini digunakan untuk mengetahui suatu data homogen atau tidak. Uji homogenitas adalah suatu prosedur uji statistik yang dimaksudkan untuk memperlihatkan bahwa dua atau lebih kelompok data sampel berasal dari populasi yang memiliki variansi yang sama (Nuryadi, dkk. 2017:89)

Sebagai contoh dalam uji homogenitas ini adalah jika kita melihat sebuah permasalahan misalakan mengukur pemahaman siswa untuk suatu sub materi dalam peajaran tertentu di sekolah berarti kelompok data yang kita jadikan sampel memiliki karakteristik yang sama, misalkan kita melakukan penelitian pada tingkat kelas dan jurusan yang sama. 


\section{DAFTAR PUSTAKA}

\section{A. Buku}

Arikunto, Suharsimi. (2010). Prosedur Penelitian: Suatu Pendekatan Praktek. Jakarta: Rineka.

Arikunto, Suharsimi. (2002). Prosedur Penelitian: Suatu Pendekatan Praktek. Rineka Cipta.Jakarta.

Baskoro, A.(2009). Panduan Praktis Searching di Internet. Jakarta : PT Trans Media.

Heri, S. (2014). Seputar Pembelajaran Sejarah; Isu, Gagasan Dan Strategi Pembelajaran. Aswaja Pressindo.

Nana Sudjana. (2005). Penilaian Hasil Proses Belajar Mengajar. Bandung: Remaja Rosdakarya.

Nuryadi, dkk. (2017). Dasar-Dasar Statistik Penelitian. Yogyakarta: Sibuku Media.

Suharsimi Arikunto. (2010). Prosedur Penelitian Suatu Pendekatan Praktik (Edisi Revisi). Jakarta: Rineka Cipta.

Supranto. (2007). Teknik Sampling untuk Survey dan Eksperimen. Jakarta: Rineka Cipta.

Susanto, H., \& Akmal, H. (2019). Media Pembelajaran Sejarah Era Teknologi Informasi (Konsep Dasar, Prinsi Aplikatif, dan Perancangannya). Banjarmasin: FKIP ULM.

Syaharuddin, S., \& Susanto, H. (2019). Sejarah Pendidikan Indonesia (Era Pra Kolonialisme Nusantara sampai Reformasi). Banjarmasin: FKIP ULM.

Umar. H. (2005). Metodologi Penelitian untuk Skripsidan Tesis Bisnis. Jakarta: P.T. Raja Grafindo Persada 2005,p. 134. 


\section{B. Hasil Penelitian, Jurnal dan Makalah}

Azizah, H. (2020). Konten Kreatif Youtube Sebagai Sumber Penghasilan Ditinjau dari Etika Bisnis Islam (Studi Kasus Youtuber Kota Metro) (Doctoral dissertation, IAIN Metro).

Ambarwati, F. (2017). Efektivitas Penggunaan Metode Pembelajaran Just In Time Teaching (Jitt) Dalam Upaya Peningkatan Minat Dan Prestasi Belajar Pada Mata Pelajaran Pkn Kelas Viii Smp Angkasa Adisutjipto Kabupaten Sleman.

Bachri, B. S. (2010). Meyakinkan Validitas Data Melalui Triangulasi Pada Penelitian Kualitatif. Teknologi Pendidikan, 10, 46-62.

Cahyono, Y. D. (2015). E-Learning (Edmodo) Sebagai Media Pembelajaran Sejarah. Jurnal Penelitian, 18(2).

Cleopatra, M. (2015). Pengaruh gaya hidup dan motivasi belajar terhadap prestasi belajar matematika. Formatif: Jurnal Ilmiah Pendidikan MIPA, $5(2)$.

Efendi, I., Prawitasari, M., \& Susanto, H. (2021). Implementasi Penilaian Pembelajaran Pada Kurikulum 2013 Mata Pelajaran Sejarah. Prabayaksa: Journal of History Education, 1(1), 21-25.

Huwaidah, A. I. (2019). pengaruh penggunaan media sosial youtube terhadap kreativitas siswa pada mata pelajaran seni budaya dan prakarya di sdn 1 nologaten ponorogo tahun ajaran 2018/2019 (Doctoral dissertation, IAIN Ponorogo).

Ihsan, H. (2015). Validitas Isi Alat Uukur Penelitian: Konsep Dan Panduan Penilaiannya. Pedagogia, 13(3), 173-179.

Mangole, K. D. B., Himpong, M., \& Kalesaran, E. R. (2017). Pemanfaatan Youtube dalam Meningkatkan Pengetahuan Masyarakat di Desa Paslaten Kecamatan Remboken Minahasa. ACTA DIURNA KOMUNIKASI, 6(4). 
Murti, B. (2011). Validitas dan reliabilitas pengukuran. Semarang: UNS.

Putra, G. L. A. K. (2019, February). Pemanfaatan Animasi Promosi dalam Media Youtube. In SENADA (Seminar Nasional Desain Dan Arsitektur) (Vol. 2, pp. 259-265).

Rasto, R., Mulyasa, E., \& Wasliman, I. (2018). Manajemen Kurikulum 2013 Dalam Meningkatkan Mutu Pembelajaran Sejarah Indonesia. Nusantara Education Review, 1(1), 37-48.

Saptono, Y. J. (2016). Motivasi dan keberhasilan belajar siswa. REGULA FIDEI: Jurnal Pendidikan Agama Kristen, 1(1), 181-204.

Susanto, H. (2015). Menghadirkan kelas Konstruktivis dalam Melatih Kemampuan berpikir Historis melalui model latihan Penelitian.

Sianipar, A. P. (2013). Pemanfaatan youtube di kalangan mahasiswa. Jurnal Ilmu Komunikasi FLOW,2(3),1-10.

Saputra, M. R., \& Riyadi, S. (2019). Sistem informasi populasi dan historikal unit alat-alat berat pada pt. daya kobelco construction machineryindonesia. Jurnal Penelitian Dosen FIKOM (UNDA), 6(2).

Siswono. (2011) Penelitian Pendidikan Matematika. Surabaya: Unesa University Press, hal. 44

Tohari, H., \& Bachri, B. S. 2019. Pengaruh Penggunaan Youtube Terhadap Motivasi Belajar Dan Hasil Belajar Mahasiswa. Kwangsan, 7(1), 286906. 